\title{
Challenge based learning in full-day schools of Germany: organization features and development factors in media pedagogical discourse
}

\author{
Denis Dubover ${ }^{1, *}$, Anastasia Peniaz ${ }^{2}$ \\ ${ }^{1}$ Don State Technical University, 1, Gagarina, 344003, Rostov-on-Don, Russia \\ ${ }^{2}$ Moscow State Pedagogical University, M. Pirogovskaya Str., 119991, Moscow, Russia
}

\begin{abstract}
In a post-industrial society, the importance of information increases at an uncontrollable rate that leads to new challenges in the educational environment and especially in general educational institutions. The aim of the article is to analyze the successful experience of project work implementation in the field of media education in Germany in the conditions of a full-day training system for analyzing the possibilities of its implementation to domestic pedagogy. Materials and Methods Observation method, expert interviews and surveys were used for data collection and processing. The research was conducted in the framework of the implementation of DAAD Research Programme at the European University of Flensburg and full-day schools in Hamburg. A sample set of empirical research includes 350 students, 25 teachers, 12 school counselors, 12 full-day school principals in Hamburg and SchleswigHolstein. Research results. As a result of the observation, an understanding of the forms and methods of project work was obtained, various relationships were established between media education, project work and the achievement of social and personal competencies (soft skills). The analyzed documents show clear dynamics in the field of legalization of project activities and understanding of the need to achieve social and personal competencies through project work.
\end{abstract}

\section{Introduction}

Media education as a phenomenon of modern pedagogy moved to a new phase: media pedagogy is becoming more and more widespread, the elements of media education are implemented at various educational levels. Also, in recent years, there has been a steady tendency towards the development and implementation of programmes aimed at increasing media and information literacy of children and adolescents, as well as students of the "silver age" at the state level. This process, on the one hand, made it possible to legalize individual pedagogical initiatives, on the other hand, the heads of educational institutions were put in an ambiguous position, they were forced to integrate media and information

* Corresponding author: denisdubover@gmail.com 
literacy lessons into the existing educational process which is hardly ready for such innovations. In confirmation of this thesis one can note several factors that hinder the implementation of mass media education: an acute shortage of media professionals among teachers, the variety of ideas concerning the ontology of media education in the context of educational levels, poor media literacy of teachers, the lack of dedicated time for project work in the schedule of the institution (schools, colleges and universities). As a result, the research questions arise that problematize this issue: What are the ways of implementation of media education programmes in countries that demonstrate a high level of media and information literacy among schoolchildren? What pedagogical, didactic and technoinfrastructural changes are required today? What approaches have the greatest impact on the development of media pedagogy? What place can media education occupy in general educational process?

The object of research is German full-day pedagogy, which pays special attention to media education and a set of didactic methods, generalized in the concept of "project work", as a leading factor in the development of school media education. In addition, in Germany, a road map of digital and media competence has been built at the state level, which should be available to all students, as well as to representatives of other educational levels. Over the past 20 years, Germany has undergone dramatic changes in the process of modernizing the education system, a vector has been chosen for the development of social and personal competencies, as a result, project work has been strengthened, and the digital environment (digital world) has been chosen as the ontological framework where you need to learn to live. A full-day school is an organizational and didactic ground for an environment the integrated development of children and adolescents. It has a high potential in the socialization and enculturation of children from multinational families.

Thus, the focus of the study is a federal state Hamburg. In particular, all schools except Junior schools are compulsory full-day schools. This form of organization allows us to proclaim project activity as the only possible one, and it often replaces homework.

The analysis of this experience is based on the research conducted in 2019, and it also takes into account the data obtained within the framework of research fellowships in 20112017 , that makes it possible to provide answers to many questions that arise during the organization of the project work in the field of media education and in any direction of pedagogy of experiential education (Erlebnis pädagogik) and pedagogy of free time (Freizeit pädgogik), aimed at the developming of social and personal competencies of students .

The study of media education as a factor in the development of various competencies demonstrates the high potential of the project work, which becomes one of the most popular tools, allowing to see the results of the educational process, master professional, social, and personal competences in the process of solving different situations related to the process of media production and usage.

Media and information education today is undoubtedly becoming one of the most important tools in the formation of meta-subject and social competencies. In addition, the promotion of mass media education in schools, universities, and centers of additional education in recent years has led to the need for new rethinking of organizational and methodological forms of its development, implementation, evaluation and further dissemination.

The development of project activities was widely discussed in the discourse of German pedagogics, where a full-day school is recognized as the dominant organizational form in general education.

The author of the article suggests his own definition of a full-day school, developed as a result of conceptual and terminological research, undertaken during the writing of Ph.D in pedagogy. «A full-day school is a multifunctional general educational institution that works 
for at least 8 hours a day and creates the conditions for the comprehensive development of students, their socialization, achievement of personal, subject and meta-subject results while mastering the basic educational program of general education by using new pedagogical developments in the field of organization and program and methodological support of the educational process and enhancing the connection of school and family by creating a special socio-cultural space " [1].

In Germany, the concept of project activities at a full-day school is becoming a key element of a holistic education system. Problems of periodization and historical development of a full-day school in Germany in the discourse of the historical development of full-day schools are analyzed by G. Ludwig [2]. Issues of modern history of full-day schools and, in particular, the project methods used at full-day schools are raised by P. Zikgraf in his works [3]. Labor education as the forerunner of project activities in terms of full-day schools has been the subject of studies in the works of Landheim [4]. Klemm's works are devoted to the study of trends in the school policy [5]. The above-mentioned works deal with such issues as the necessary conditions for the development of the educational process, where practical work and labor education occupy an important place. These theoretical views find conceptual parallelism in the works of a Russian teacher E.G. Kostyashkin, who, in his turn, described the experience of the practical implementation of labor education in a full-day school [6]. His experience influenced upon the development of German pedagogy in the German Democratic Republic in the 1960s [7]. The theory and practice of implementing the model of full-day education in the conditions of updating the school system of Germany are discussed in detail in the works of Sh. Appel [8], who created classifications, theoretically comprehended various types of full-day schools, Yu. Rekus [9], who created a model of legal support for the activities of full-day schools, L. Stecher [10], who created a model of developing pedagogical technologies in full-day education. G. Rutz [11] described project work in the field of media education and the use of technologies for field practice-oriented events and justified the thesis: "Modern children want to understand what they are studying for, where they can apply their knowledge". G. Holtappels carefully accumulates and analyzes statistical materials concerning the development of full-day education in Germany [12]. The concepts of health saving technologies in full-day schools and the rhythmization of the educational process are reflected in the works of K. Höeman [13]. The problems of a balanced organization of time, as well as structuring of the day and the rhythmization of the educational process, are deeply analyzed by such researcher as W. Magnus-Finger [14]. The most promising is the study of the method of project work in the field of media and information education in the practice of German pedagogy, especially in the conditions of developing full-day schools, which are based on the concepts of pedagogical instrumentalism. Nowadays, there are three main directions of implementation of the ideas of pedagogical instrumentalism, according to which the human body is a kind of «tool» for understanding the world. O.D. Fedotova notes that «by analogy with the grammatical construction proposed by J. Dewey, they took the form of the following theses: learning by going, learning by feeling, learning by doing».

As it was established by O.D. Fedotova, the key approach to organizing project activities in full-day schools in Germany dates back to F. Hanzberg's broad interpretation of the concept of «practice». This concept includes the process of «doing» as a spontaneous functioning used to establish connections between subjectively unknown elements of the spiritual and material world. It also includes the aspect of "action" as an individual activity, realized in accordance with the personal need in cultural and historical contexts [15].

Also, according to L. Clemson, it is the combination of project technologies and media education that implies the achievement of critical thinking through the phenomenon of gaining experience through living in various situations (educational and extracurricular), that is at the core of project work [16]. 
S. Traubs' monograph considers project work in terms of the formation of personal and social competencies. Thus, the author notes that "...students have ceased to be passive consumers of information, they are ready for active and constructive production and processing of new knowledge" [17]. Hermut von Hentig offers to consider project work through the prism of achieving of four types of competencies: "professional" (Sachkompetenz), "methodical" (Methodische Kompetenz), "social" (Soziale Kompetenz) and "personal" (Personal Kompetenz). According to the author, the most significant are methodical and personal ones, since they actually require the presence of social competencies, and without mastering professional ones, it is impossible to perform an action with the predicted result. Hartmut von Hentig defines methodical competence as the competence that "allows you to find ways to solve a problem, select the necessary tools, tools that can be applied to solve a problem". At the same time, he attributes the following properties to personal competencies: "Personal competencies can be correlated with responsibility competencies. The student must develop his world but in harmony with other members of a society. Personal competencies require the development of a sense of responsibility in making decisions and solving problems, and they are also closely related to the communication process. [18]

Questions of media educational training for teachers are highlighted in the articles of $\mathrm{M}$ .Haller, who notes that "..it is necessary to provide adequate training and support for teachers at all educational levels in order to meet the complex requirements of media education in schools. It seems even more surprising that, unlike many different models of school media education at the beginning of the project, it is hardly possible to find any comparable models of teacher vocational media education" [19]

Development of news literacy and critical thinking by means of media education is an important issue in J. Gasser's works. The author focuses on the fact that issues of fake news today are perceived as a real threat to the stability of society and democracy [20]. Also, the context of the development of media literacy in mixed forms of education is reflected in the publication of the author in a team of co-authors on the example of the development of media and information literacy in the process of learning foreign languages [21].

\section{Materials and methods}

This article is the result of a theoretical and empirical analysis of the organization of project work in Hamburg full-day schools in 2011-2019.

The research was conducted on a sample of 12 district schools, 350 students, 25 teachers, 12 social workers, 10 coordinators of the second half of the day, 12 principals of full-day schools of Hamburg, the Chairman of the Union of full-day schools in Germany Mr. S. Appel, the head of Media education department of Land Institute of teachers and school development in Hamburg - Ingo Kribisch, professors of University of Flensburg (Europe Universität Flensburg ) Christian Filk, Jurgen Budde, Georg Konstantinov, Joszi Sorokowski, professor of Leuphana University (Lüneburg) - Maria von Salish and others.

The documentary ground of the analysis comprises legal, regulatory, administrative, and methodological materials governing the educational process in a full-day school in Germany, pedagogical periodicals, and official websites of the ministries of federal education, trade unions, research centers and full-day schools in Germany.

Methods of empirical research: expert interviews, in-depth interviews, surveys, observation. 


\section{Results}

The creation of new organizational and methodological conditions in full-day schools leads to a conceptually new understanding of the content of the educational process and the development of media education. The movement vector of modern full-day schools is directed towards the spread of the compulsory form of education, which makes it possible to introduce and put into practice technologies based on increasing the amount of time students spend in school. The results of the analysis of the potential of various types of fullday schools show that this particular form involves the creation of an individualized system of training and the use of technologies such as individual educational routes, "pedagogy of free time» and the use of a break as an additional educational resource. Also, the organization of independent work, presented in various forms, becomes an important element of the activities of children and adolescents in schools of this type [22].

One of the most acute problems that are highlighted by the interviewees - is performing homework. With the variety of options for implementing this type of activity in modern German full-day schools, there is a growing tendency to move away from the classical model of homework to independent work to deepen the material covered (project activities, case technologies, creating presentations, preparing reports). Also, often independent work does not focus so much on consolidation of material covered, as on the expansion of ideas on the subject, thereby "homework" is combined with the study of new material, as well as with the training of basic students' competencies and deeper comprehension of the learning material.

However, the development of modern full-day schools in the mandatory form is increasingly moving along the path of introducing the method of project work as a leading element of students' independent activity. One of the key modern developments in the development of self-acting competencies in Germany is SOL-self-organised learning (Selbst organisiertes Lernen).

The introduction of this technology, which also includes new forms of homework organizing, prepares students for the key methods of independent and collective work [23]. This method is not connected with the organizational capabilities of full-day schools. It is applicable both in a voluntary-type full-day school and in a part-time school. Namely a fullday form reveals project work's pedagogical potential, applying a step-by-step structure for mastering competencies and the principle of nonlinear didactics, which is applicable in practice in the form of project activities and other forms of extracurricular activities. Project work becomes a kind of independent work, aimed at deeper comprehension of the acquired knowledge, as well as at the formation and development of different competencies in the areas of studied subjects, the ability to navigate in a complex multi-level media space of the digital society and the skill to find and process information independently, analyze the data. Work in project groups provides the opportunity for children with different types of perception of information to comprehend the studied material in a more effective way. The organization of project work in a full-day school carries special opportunities. Firstly, being in school all day long students can fulfill project work not detrimental to the main process, and secondly, organizational and temporal capabilities of full-day schools allow to realize project work using the resources of both the school and third-party partner organizations (institutions of continuing education, sports unions, public organizations).

During indoor lessons, the teacher offers students a set of materials and documents (case) on a specific topic and sets the deadline for completing this assignment. Hours allocated for free time at the choice of the student are distributed throughout the week to prepare their projects, which cover the main academic disciplines. For example, in the district school Poppenbuttel (as well as in other full-day schools in Hamburg and Germany), in addition to the indicated free time, there are «Project weeks» with no classes 
and students spend all day in preparation to the presentation, which will take place at the end of the week. So, students of different age and level of preparation fulfill various projects. As a part of creating a presentation for the «traditional German culture» project, the 5th grade is divided by the head and social teacher into several subgroups: students who need to strengthen various educational competencies receive those tasks that will contribute to their consolidation. But regardless of the topic, such projects are aimed at developing digital (media) competence. For example, this project involves a comprehensive work aimed at the search and collection of data from various sources (mainly encyclopedias), analysis and data processing, the creation of visual elements for presentation (costumes, posters, electronic presentations. In addition, several students cook various dishes of traditional German cuisine right in the classroom: dough is kneaded and donuts are made on one desk, on the other desk-donuts are fried.

This type of activity develops, in addition to educational competencies, competencies of group communication, the ability to build a dialogue with a «partner» and teamwork, and also allows showing leadership qualities by taking the organization of classwork and control over subgroups aimed at improving the timeliness and quality of project implementation. The senior students create natural science projects and cultural presentations, for example, European culture of the 1920s.

As a major event, the school holds such weeks several times a year. And each time an original theme is selected, which finds its implementation at all school levels from the first to the 10th grade.

An analysis of the curricula of the studied schools suggests that the most common model is the organization of six project levels, which begin with the 5th grade. The experience of a full-day Hamburg gymnasium (Max-Bauer-Schule), which implements a project-based learning system consisting of six stages varying in difficulty level, is interesting to study. All six project steps are subordinated to a single structure and cover the entire range of school subjects: German, mathematics, social studies, natural sciences, art, religion and ethics, labor education, music, sexual education, social and legal education, media education, health conservation, cross-cultural upbringing, teaching traffic rules, career guidance, collective activity. Depending on the specifics of the project, the emphasis is placed on certain disciplines.

The first project block is «We Meet». Using the selected matrix for the analysis of project work, one can introduce all areas of project activity in the studied school. Learning German is presented in the following tasks: «We get to know each other»; "Conducting interviews and surveys"; "Description of the interlocutor"; "Our stories."

As part of the preparation and implementation of this project, students develop their interpersonal communication skills, and also learn to collect, process, analyze the information received, they learn to identify essential core elements of information, conduct surveys, compare data. Besides, this area of project activity contributes to building a positive microclimate in the team.

Work on art project includes creation of self-portrait, an artistic birthday calendar, writing an essay on the topic " That's how I used to be", visualization of various data.

Sex education is presented in the project work on the following themes: "Boys and girls", "Conflicts and friendship", etc. Learning the basics of social science begins with studying the path to school, a residential area, family history, as well as self-orientation lessons in the city of residence. The mathematical part of this project includes the calculation and statistical processing of all elements of the activity: "Surveys and assessments"; "Creating charts of all types", "Statistical calculations"; "Creating a calendar of birthdays". As students got promoted from one grade to the next one, project tasks become more complicated and narrowly focused. An analysis of the topics of project 
activities in various grades leads to the conclusion that the project work is directly connected not only with the curriculum but also with the interests of students.

Project activities in the 6th grade of the studied school as well as in the fifth consists of six projects: Language project - "Children's Book" (German); "We are all children of the whole world" (religious education and social sciences); Music (music and art); Friendship and sex (natural sciences, German); Energy (natural sciences); Life in the Middle Ages (social studies). Project activity in the 7th grade acquires an even narrower thematic focus and is focused on two areas: natural sciences and social studies.

An analysis of the project activities of students in grades 5-9 in Hamburg by observation allowed us to study various types of this educational activity both in content and in the form of organization. Besides projects aimed at developing basic competencies, there are projects that are designed to develop athletic qualities, independence, maintain the health of students, learn to navigate the local area.

In organizing project activities, much attention is paid to the idea of practical orientation in training. Dealing with the organization of full-day education, Reinhard Kail formulated the fundamental principle of modern German general education: "Children and teenagers do not want to learn just like that, they need to know why they are learning something, where they can apply their knowledge» («Der Raum ist der dritte Pädagoge», Plenary report, Congress of the German Full-Day School, Erfurt, 2011). Practical orientation is the key concept in the organization of project work, conceptualizing educational activities.

It is interesting to study the organization of project work in a full-day school in Hamburg (Stadteilschule Allermöe), where great importance is given to project work in the field of media education. From the fifth grade on, children are involved in media educational activities based on simple tasks, such as a regular filling and analyzing a table of media consumption, that helps to build their ideal model of interaction with the media world.

Then, the process of mastering more complex technologies in the design and production of a media product begins. For example, in the 6th grade, students get acquainted with such managerial and marketing tools as the mental map of the project. So, in the school radio project, it is necessary to fill in the rays emanating from the central core that diverge clockwise with all the elements of the future project: editorial office (music, noise, studio), promotion (print flyers, SMM ), journalists (sound engineers, DJs, correspondents), air moderation (live broadcasts, calls, receiving messages, voting), etc.

To fill in this mental map, it is necessary to build a teamwork process, communication with key stakeholders (school administration, teacher, urban community, external experts), which creates enormous conditions for the development of social and personal competencies using media education as part of a project work at a full-day school.

According to the experts interviewed, this form of work within full-day schools develops the competencies of project thinking, which inevitably requires the development of a whole range of competencies that are difficult to measure in schools. Everyone agrees that the achievement of social and personal competencies is beyond doubt. Nowadays, these competencies are becoming fundamental to life in a digital society with complex relationships. However, nowadays, there are no representative scales for measuring the achievement of these competencies, both in schools and universities. As a rule, they are determined "by eye". A teacher of the University of Flensburg Yostsi Sorokovsky (Joszi Sorokowski) gave an expert interview, in which he mentioned that "...media education, both as a goal and as a means, can play a huge role in developing thinking, digital competencies, and enhancing social interaction. But it is almost impossible to measure it. If we use the scales used to measure the competencies of employees of companies, we can miss a lot, because students' social experience is very mobile, they are still children and a lot depends on the teacher. Staging and evaluating these groups of competencies is an art, 
and the teacher resembles a director who creates on stage with his students". An experienced teacher can easily distinguish a student who may or may not take responsibility or interact with other members of the project team, has leadership qualities and is ready for stressful situations. But such an assessment can hardly be considered objective. In the human resources sector, there are many tools for assessing soft skills, but they are not available for mass education due to excessive costs. Also, psychological assessment methods cannot reach all students in all schools. Thus, according to the interviewed experts, one of the most effective ways to check the achievement or failure to achieve competencies is to conduct regular pitches with the results of project work, where students are forced to demonstrate the peculiarities of their relationships with classmates and demonstrate the results of their work and personal contribution.

At the same time, the attitude of schoolchildren towards full-day schooling is becoming mixed. Figure 1 shows that the assessment depends greatly on the level of motivation and awareness. For example, high school students often see a full-day school as a tool that allows them to focus more on those tasks that they are interested in and that they need to move forward. They note that they like a full-day school, but under certain conditions: for example, they like the opportunity to form the second half of the day, or choose certain additional subjects based on their needs. At the same time, students in grades 5-7 are more satisfied, in particular, because the project work allows them not to do home assignment at home, as it usually happens in the case of part-time schools.

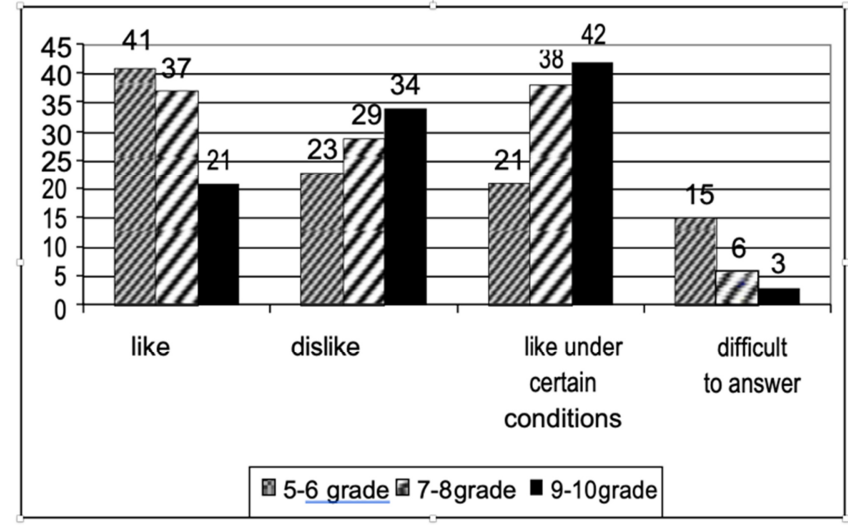

Fig. 1. Attitude of German students to the model of full-day schools (in \%).

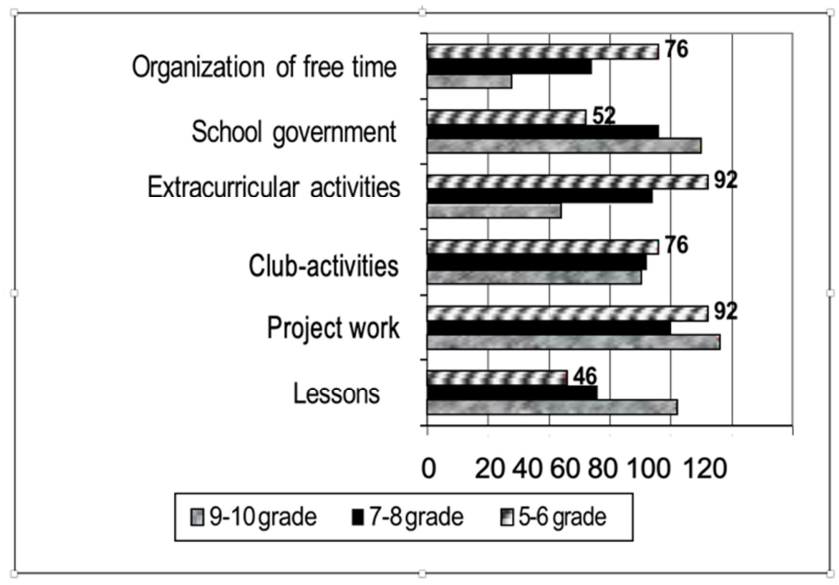

Fig. 2. Attitude of students to various types of activities in a full-day school in Germany. 
Figures 1 and 2 show the results of a survey of high school students who were asked to answer the question: "Do you like to study at a full-day school?" More than $40 \%$ of students in grades 8-9 have a positive assessment of the full-day education system. Project work and extracurricular activities are evaluated equally by students in Hamburg and Flensburg (Figure 2). This emphasizes the importance of project work as a factor in the development of competencies. More than $30 \%$ of the 350 students surveyed said that they are engaged in conscious media creation, the rest referred to the use of media tools for working on projects. Thus, we can conclude that it is the project work that stimulates the development of media education in school. It is promising to measure the level of media literacy in schools with and without project work.

However, the expert interviews and observation made it possible to identify the acute problem of involving children from migrant families in the project work, and, as a result, achieving social and personal competencies (in this context, the reason for migration does not matter). More than $70 \%$ of the teachers surveyed expressed concern that there is no dialogue with children from these families, both on the part of teachers and classmates. It happens due to the national mentality, as well as cultural and religious background, some immigrant families refuse to cooperate with schools, as a result, it hampers the dialogue, and complicate the adaptation and integration of children and adolescents. The survey participants highlighted the following reasons: the language barrier that complicates communication between parents and the school, the distribution of gender roles in many traditional families, in which mother does not contact an outside world, doing housework and raising children, and father is busy with work from morning till night.

The conducted observation and questioning of children from migrant families in the studied schools has led to the following conclusions:

- the problem of adaptation of the majority of schoolchildren aged from 10 to 17 is recognized as important for successful schooling $(68 \%)$;

- at the same time, $42 \%$ of migrant students do not see a problem in the current situation, indicating a biased attitude on the part of the school administration and teachers;

- $14 \%$ of respondents do not consider it necessary to accept the national German culture, considering it to be alien, and indicating that they moved to Germany due to the will of the parents.

These circumstances lead to disunity of migrant children in the school team, the formation of micro-groups according to the ethnic principle both in school and beyond, as a result children and adolescents lose their motivation to study the German language, as well as self-identification as a member of German society. They often manifest deviant behavior towards classmates and teachers, outbreaks of unreasonable (in terms of logic of behavioral stereotypes in school) aggression. So, during an interview with the principal of the district school in Hamburg, an incident was noticed, which, according to the principal, is not a single occurrence, but rather represents a system of behavior for migrants from Middle East countries, especially such as Iraq and Afghanistan: the teacher brought to the school principal a student, who did not want to obey school rules. Despite calm explanations concerning the need to adopt established standards and stop aggressive behavior towards teachers, the teenager did not change his behavior and continued to speak rudely in broken German, after it he was sent to a school psychologist.

As a solution to this problem, the interviewed school administration officials call for the following measures:

- creation of the apparatus of social educators- representatives of the immigrant community: Turks, Iranians, Afghans, Russians;

- systematic work with parents aimed at solving problems in the education and behavior of the child; 
- creation of an organizational model that helps to increase motivation among migrant children and adolescents for integration in German cultural space.

According to the studied expert community, it is media projects that can bring together a divided society, as media consumption as a process is the only thing that connects adolescents in the communication process.

\section{Discussion and conclusion}

Project work in the discourse of social and personal competencies development allows us to consider the concept of «full-day school» not only as an educational level but also as a developing environment with co-learning, collaboration, co-working, networking, and coliving. Taking into account modern concepts (for example, the concept of perceiving space as a third teacher), the peculiarities in the organization of project work as the only possible form of interaction of the students with the world of knowledge, the transformation of media education as a discipline of choice within the framework of extracurricular work contributes to an effective living social experience necessary for the formation of a sustainable and adaptive interaction with a dynamically changing world, which is expressed in the achievement of social and personal competencies. Project work in the field of media education is both an independent direction (school radio, television, newspaper, web site, blogs in social networks and social media), and a provider of social and personal competencies for the educational process in general. Project work has a positive effect on the development of motivation, awareness, goal-setting, project thinking and thoughtgenerating competencies of personal development.

This experience seems to be useful for analysis, interpretation and adaptation in domestic conditions, where the concept of «full-day school» can be understood not only as an organizational structure, but as the principles of building the educational process based on individualized development of the student, the formation of competencies for determining one's needs, which is consistent with goals, and the ability to create one own development track, based on the opportunities of the educational organization.

The development of media education within the framework of project activities and at various stages is also reflected in the report of the Ministry of Culture, which describes media competencies. This list is exhaustive and demonstrates significant dynamics from an utilitarian approach to media education (where media literacy was understood only as the ability to use devices, find information, distinguish fakes, and monitor reputation in social networks) to a cultural one. Thus, the following six key groups of competencies are offered: the ability to find, process, and save; evaluate, save and retrieve; communicate and interact; create and present; maintain and provide security; solve problems and act; analyze and reflect. In the context of our study, the competencies that form the ability to analyze and reflect, solve problems and act are the most significant. These groups of competencies can be characterized as social and personal competencies. Thus, it is certain that modern educational policy in Germany has recognized the importance of media education as a tool for the development of social and personal competencies through project work. This document actually consolidated the results of many years of discussions, giving the opportunity to focus on the best practices and discuss possible models in the development of these competencies in the developing digital world [24].

For many years, public discourse has postulated that "a democratic law state is based on the responsible participation and cooperation of its citizens, as well as their willingness to make their own socially responsible decisions" (Detjen, 2018) [25]. On the other hand, universities are often accused of not educating students in practical and subject areas (Kergel \& Heidkamp, 2018) [26]. Also relevant is the issue of general cultural and aesthetic education in a full-time school [27]. 
In order to eliminate this contradiction between the goal of focused specialized training and the simultaneous development of personal competencies, didactic methods, which take into account both requirements and the holistic development of students, are becoming increasingly important.

Thus, media education in the pedagogical projection of full-day schools in Germany (and in particular Hamburg) is becoming both a means of increasing the students' motivation and the goal aimed at developing media and digital literacy. The most interesting issues for further analysis are the study of the influence of media education on the development of various groups of competencies: professional, personal and social. Also, the study will allow to establish the readiness of teachers to these changes. The experience gained can be applied in Russian pedagogy. Nowadays, both media education and project work are increasingly being discussed at the level of government, universities, and schools.

\section{References}

1. D.A. Dubover, Features of the formation and development of full-day schools in Russia and Germany: a comparative analysis: Abstract. Diss. (2013)

2. H. Ludwig, Deutsches Institut für Internationale Pädagogische Forschung 51(2), 277279 (1993)

3. P. Zickgraf, Eine kurze Geschichte der Ganztagsschule, http://www.ganztagsschulen.org

4. V. Ladenthin, J. Rekus, Die Ganztagsschule. Alltag, Reform, Geschichte, Theorie (Weinheim, München 2005)

5. K. Klemm, Kaiserslautern 4, 135-136 (2012)

6. E.K. Kostyashkin, Extended day school (Moscow, 1965)

7. D.A. Dubover, Education. The science. Innovation: The Southern Dimension 5, 21-26 (2012)

8. A.S. Handbuch, Ganztagsschule. Praxis - Konzepte - Handreichungen (Wochenschau Verlag, Auflage, 2004)

9. J. Rekus, Die Ganztagsschule (Weinheim, München 2007)

10. L. Stecher, H.-H. Krüger, Zeitschrift für Erziehungswissenschaft. Sonderheft 15 (Wiesbaden, VS, 2011)

11. G. Rutz, Gutachten zur Ganztagsschule (Frankfurt, Main, 1968)

12. H. Holtappels, A.H. Ludwig, U. Rother, G. Rutz, Entwicklung und Qualität von Ganztagsschulen. Bilanz des Ausbaus auf der Basis der Froschungsbefunde von StEG (Jahrbuch Ganztagsschule. Schwalbach, Wochenschauverlag, 2012)

13. K. Höhmann, H. Holtappels, T. Schnetzer, Konzeptionen, Forschungsbefunde, aktuelle Entwicklungen (Juventa Verlag, Weinheim, 2004)

14. U. Magnus-Finger, Rhythmisiertes Lernen in der Schule: unter Berücksichtigung des lernbehinderten Schülers (Jarick, 1979)

15. O.D. Fedotova, Action as a tool of knowledge in the instrumentalist pedagogy of Germany. Innovative approaches in the educational process (Ryazan, 1998)

16. L. Clemson et al., Erfahrungen und Erlebnisse mit dem LiFE Programm, Aktiv und sicher durchs Leben mit dem LiFE Programm (Springer, Berlin, Heidelberg, 2018)

17. S. Traub, Projectarbeit erforderlich gestaltet (Verlag, Bad Heilbrun, 2012) 
18. Von Hentig H. Die Schule neu denken. - München: Hanser, 1993. - With . thirty.

19. M. Haller et al., MedienPädagogik: Zeitschrift für Theorie und Praxis der Medienbildung 36, 143-157 (2019)

20. G.J. Fake, News und Meinungsbildung in der Menschenrechtsprofession. Das Propagandamodell zur kritischen Medienpädagogik (2019)

21. E. Soltovets, O. Chigisheva, D. Dubover, Dilemas Contemporáneos: Educación, Política y Valores 6, 3 (2019)

22. D.A. Dubover, Internet magazine Science 4(13) https://naukovedenie.ru/PDF/32pvn412.pdf

23. P.S. Braunschweig, C. Kappler, E. Chiapparini, International Journal About Parents in Education 11 (2019)

24. C. Bogedan, Strategie der Kultusministerkonferenz Bildung in der digitalen Welt Präsidentin der Kultusministerkonferenz Senatorin für Kinder und Bildung in Bremen (2018)

25. J. Detjen, Kompetenzorientierung (Springer VS, Wiesbaden, 2018)

26. D. Kergel, B. Heidkamp, Hochschulen im Spannungsfeld der Bologna-Reform (Springer VS, Wiesbaden, 2018)

27. R. Hampe, Kreative Lernfelder: Künstlerische Therapien in Kultur-und Bildungskontexten 3, 208 (2009) 